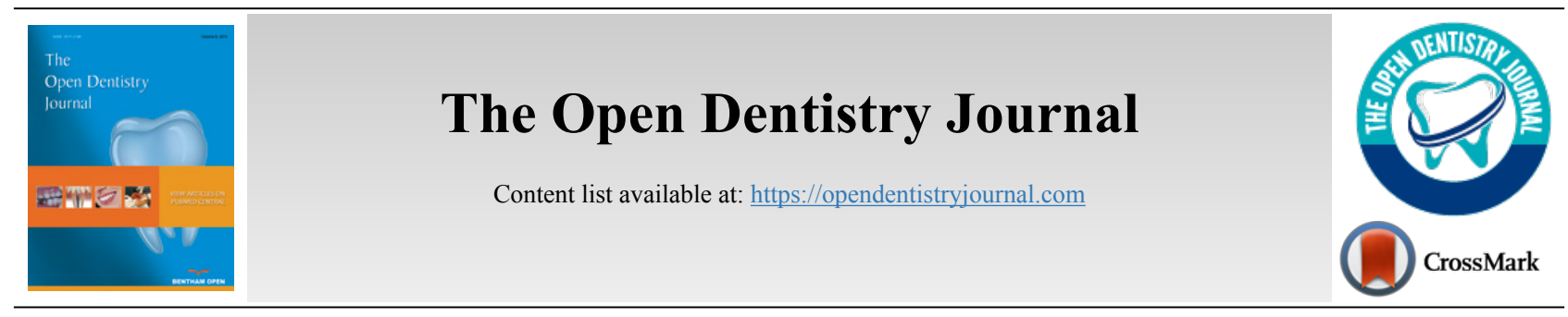

RESEARCH ARTICLE

\title{
Coronal Restorations and Temporomandibular Joint (TMJ) Dysfunction: A Survey Among General Practitioners of the Town of Abidjan
}

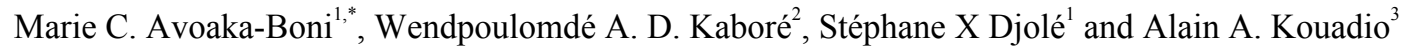 \\ ${ }^{1}$ Department of Conservative Dentistry and Endodontics, Félix Houphouët Boigny University, 22 BP: 612 Abidjan 22, Ivory Coast \\ ${ }^{2}$ Department of Conservative Dentistry and Endodontics, Research Center of Health Sciences, Joseph KI-ZERBO University, 03 BP 7021 \\ Ouagadougou 03, Burkina Faso \\ ${ }^{3}$ Department of Prosthodontics, Félix Houphouët Boigny University, 22 BP: 612 Abidjan 22, Ivory Coast
}

\begin{abstract}
:
Background:

The paper surveyed the knowledge of general practitioners to coronal restorations and temporomandibular dysfunction. The specific aim of this study was to evaluate the knowledge and therapeutic approaches of the general practitioners in terms of restoring occlusion, aesthetics and function after restorative treatments in other to make recommendations to prevent potential dysfunction of the temporomandibular joint.

Methodology:

A cross sectional descriptive survey was used. It was carried out on 86 dentists out of the entire population size of 152 dentists practicing within Abidjan's center municipality, randomly selected from the database provided by the National College of Dental Surgeons of Ivory Coast. A structured questionnaire was administered to collect data, which was subsequently collated and analysed.

\section{Results:}

The majority of the practitioners $(95.4 \%)$ knew how to diagnose TMJ dysfunction. The etiological factors were stress for $55.2 \%$ of the practitioners and amalgam overhang for $49.4 \%$ of them. The precautions used to avoid TMJ disorders consisted of good control of the occlusion after having performed a restoration (55\%) and taking into account the occlusal morphology (32\%) at the time of shaping. Fifty-four percent of the practitioners systematically reevaluated the restorations undertaken.

\section{Conclusion:}

Impairment of occlusion results in improper muscular responses and leads to changes in pressure at the level of the temporomandibular joint. This study revealed that the general practitioners of the town of Abidjan have a good level of knowledge of the consequences of poorly carried out restorations on the initiation of masticatory apparatus disorders.
\end{abstract}

Keywords: Coronal restorations, Dental occlusion, Disorders, Temporomandibular joint, Recommendations, Ivory Coast, Survey.

\begin{tabular}{|c|c|c|c|}
\hline Article History & Received: September 21, 2019 & Revised: October 29, 2019 & Accepted: December 03, 2019 \\
\hline
\end{tabular}

\section{INTRODUCTION}

The aim of dental restorations is to reconstitute the initial morphology of the teeth so as to allow them to again assume their various functions in the masticatory apparatus. They are an important component of daily practice and represent $40 \%$ of the procedures performed [1]. They involve the use of various entities such as composite materials with adhesive systems,

\footnotetext{
Address correspondence to this author at the Department of Conservative Dentistry and Endodontics, Research Center of Health Sciences, Joseph KIZERBO University, 03 BP 7021 Ouagadougou 03, Burkina Faso; Tel: +22670211283; E-mail: dr_kabor@yahoo.fr
}

amalgams, and glass-ionomer cements that should allow reestablishment of function and occlusion [2]. Occlusion must be controlled and the normal function needs to be reestablished by a proper fit [3]. When occlusion is not reestablished, dysfunction can occur, particularly repeated fracture of obturations, occlusal trauma, enhanced looseness of the teeth, movement or dislocation of teeth, attrition of the hard dental tissues and of the restorations $[3,4]$. Such dysfunction can also manifest as disorders of the masticatory muscles or of the Temporo mandibullary Joint (TMJ) [5]. Dental occlusion plays a major role in the functions of the masticatory apparatus $[6,7]$. Indeed, 
it influences the mandibular posture at rest, the mandibular kinetics, mastication, swallowing, the loads applied to the TMJ, and the trajectories play a major role during Maximized Intercuspal Occlusion (MIO) [8]. As stated by Orthlieba et al. (2016) [9], the TMJ and dental occlusion are "linked, for better or for worse" even if a direct correlation between all TMJ and occlusion is still controversial.

In light of this, it struck us that it would be important to evaluate the level of knowledge and the approaches of general practitioners of the town of Abidjan in terms of the quality of occlusion control after restorative treatment in order to be able to make recommendations to prevent potential TMJ disorders.

\section{METHODOLOGY}

\subsection{Setting, Period, Population and Type of Study}

This was a cross-sectional descriptive survey that took place at Abidjan in Ivory Coast from February to April 2014. It involved administering a structured questionnaire to 86 dentists selected independently of gender, and all of them were registered with the National College of Dental Surgeons of Ivory Coast. They were randomly selected. The sample size of 86 practitioners was used out of the population of 152 . The respondents included dentists of less than 5 years practice experience, practicing both in private and in public facilities, within Abidjan center municipality. These localities were chosen because they have a high concentration of practitioners or representative of the dentists that practice in Ivory Coast. Dentists in training were not included.

\subsection{Execution of the Survey}

A survey form was designed with relevant and adequate requirements of the study, with three sections. The first was in regard to socio-professional data (the type of practice, the number of years of experience). The second section evaluated the knowledge of the practitioners regarding TMJ disorders (the manifestations, the causes, the treatment), and the third evaluated the precautions taken when carrying out direct restorations (means of prevention). The survey then included self-administration of the questionnaires. The survey form was dropped off at the dental practice by the surveyor and filled out by the dentist. After manual inspection of the data to verify the forms had been filled out, analysis of the data was carried out using Microsoft Office Word version 2013 and Epi-info version 6.01 (Centers for Disease Control and Prevention, Atlanta, Georgia, United States of America) software. The results obtained were presented as tables using Excel and Word 2013 software with Windows XP professional.

\section{RESULTS}

\subsection{Socio-professional Characteristics of those Surveyed}

Of the 152 dentists questioned, 86 completed the questionnaires, amounting to a participation rate of $56.6 \%$ and a sex ratio of 1.68 . Of the surveyed practitioners, $49.5 \%$ practiced in the private sector while $50.5 \%$ practiced in the public sector. Practitioners with more than 10 years of experience $(48 \%)$ were the most represented (Table 1). The majority $(89.7 \%)$ participated in continued post-university training.

\subsection{Knowledge Regarding TMJ Disorders}

The majority of the practitioners $(95.4 \%)$ knew how to diagnose a TMJ disorder, although the frequency of the diagnosis was $59 \%$ for those who had encountered it only a handful of times (Table 2). The reported clinical signs were: joint pain according to $76 \%$ of the practitioners, joint noise according to $64.4 \%$, and muscle pain for $69.9 \%$ of them (Table 3 ). The etiological factors noted by the practitioners were stress for $52 \%$ and overhanging amalgams for $49.4 \%$ of them (Table 4 ). For the practitioners, the treatment of TMJ disorders amounted to selective grinding $(70.1 \%)$ and wearing a mouthguard $(65.5 \%)$. Medication-based therapies with myorelaxants were also used (Table 5). In case of pain at the level of the TMJ following coronal restorations, $54 \%$ of the practitioners proceeded with correction and reevaluation. Nonetheless, $65.5 \%$ of the practitioners revealed that they referred patients to a specialist in this area, an occlusodontist or a maxillofacial surgeon.

Table 1. How long the dentists had been in practice.

\begin{tabular}{|c|c|c|}
\hline Years of Practice & Number of Practitioners & Percentage (\%) \\
\hline < 5 years & 21 & 24 \\
\hline 5-10 years & 24 & 28 \\
\hline > 10 years & 41 & 48 \\
\hline Total & 86 & 100 \\
\hline
\end{tabular}

The above table shows that the practitioners have adequate practice experience considering the number of dentists that have practiced above 5years (65).

Table 2. The frequency at which TMJ disorders were diagnosed by the practitioners.

\begin{tabular}{|c|c|c|}
\hline Frequency of Diagnosis of the TMJ Disorder & Number & 23 \\
\hline Rarely & 50 & 8 \\
\hline Sometimes & 59 & 5 \\
\hline Often & 9 & 6 \\
\hline Never & 86 & 100 \\
\hline Total & 5 \\
\hline
\end{tabular}

59 respondent agree with sometimes and often which is an indication of awareness and occurrence of TMJ DISORDER among dental practitioners. 
Table 3. Manifestations of TMJ disorders according to the practitioners.

\begin{tabular}{|c|c|c|c|c|}
\hline \multirow[t]{2}{*}{ Manifestations of the Disorders } & \multicolumn{2}{|c|}{ Yes } & \multicolumn{2}{|c|}{ No } \\
\hline & Number & Percentage (\%) & Number & Percentage (\%) \\
\hline Toothache & 14 & 16.1 & 72 & 82.8 \\
\hline Joint pain & 66 & 75.9 & 20 & 23 \\
\hline Muscle pain & 53 & 60.9 & 33 & 37.9 \\
\hline Back pain & 12 & 13.8 & 74 & 85.1 \\
\hline Joint noise & 56 & 64.4 & 30 & 34.5 \\
\hline Projections & 32 & 36.8 & 54 & 62.1 \\
\hline Headaches & 38 & 43.7 & 48 & 55.2 \\
\hline Other types of pain & 4 & 4.6 & 81 & 93.1 \\
\hline Total & \multicolumn{2}{|c|}{226} & \multicolumn{2}{|c|}{458} \\
\hline
\end{tabular}

8 types of manifestations were listed, the total number of practitioners that responded YES were 275 in cumulative to all the manifestations. While 412 practitioners responded with NO in cumulative to all the manifestations. 86 questionaires were collated taking each of the manifestation one after the other. It shows that the practitioners have the knowledge of the different manifestations of TMJ disorder.

Table 4. The etiological factors for TMJ disorders according to the practitioners.

\begin{tabular}{|c|c|c|c|c|}
\hline \multirow[t]{2}{*}{ Etiological factors for TMJ Disorders } & \multicolumn{2}{|c|}{ Yes } & \multicolumn{2}{|c|}{ No } \\
\hline & Number () & Percentage (\%) & Number & Percentage (\%) \\
\hline Stress & 48 & 55.2 & 38 & 43.7 \\
\hline Inadequate protheses & 28 & 32.2 & 58 & 66.7 \\
\hline Misaligned teeth & 76 & 87.4 & 10 & 11.5 \\
\hline Overhanging amalgams & 43 & 49.4 & 43 & 49.4 \\
\hline Insufficient amalgams & 4 & 4.6 & 82 & 94.3 \\
\hline Overhanging composites & 19 & 21.8 & 67 & 77 \\
\hline Insufficient composites & 3 & 3.4 & 83 & 95.4 \\
\hline Other causes & 5 & 5.7 & 77 & 88.5 \\
\hline Total & \multicolumn{2}{|c|}{226} & \multicolumn{2}{|c|}{458} \\
\hline
\end{tabular}

The total number of practitioners that responded with YES to the 8 LISTED etiological factors is 226 in cumulative, while 458 practitioners responded NO to the factors also in cumulative. After the collation of 86 filled questionares taken the etiological factors one after the other .It shows that all the practitioners have adequate knowledge of the etiological factors and managed the disorders based on individual approach

Table 5. Treatment of TMJ disorders according to the practitioners.

\begin{tabular}{|c|c|c|c|c|}
\hline \multirow[t]{2}{*}{ Treatment of the Disorder } & \multicolumn{2}{|c|}{ Yes } & \multicolumn{2}{|c|}{ No } \\
\hline & Number & Percentage (\%) & Number & Percentage (\%) \\
\hline $\begin{array}{c}\text { Mouthguard } \\
\text { Selective grinding } \\
\text { Renewed coronal restorations } \\
\text { Endodontic treatment } \\
\text { Restoration by a fixed prosthesis } \\
\text { Other }\end{array}$ & $\begin{array}{c}57 \\
61 \\
36 \\
4 \\
19 \\
21\end{array}$ & $\begin{array}{c}65.5 \\
70.1 \\
41.4 \\
4.6 \\
21.8 \\
24.1\end{array}$ & $\begin{array}{l}29 \\
25 \\
50 \\
82 \\
67 \\
61\end{array}$ & $\begin{array}{c}33.3 \\
28.7 \\
57.5 \\
94.3 \\
77 \\
70.1\end{array}$ \\
\hline Total & \multicolumn{2}{|c|}{198} & \multicolumn{2}{|c|}{314} \\
\hline
\end{tabular}

The number of dentists that responded with YES using 86 questionaires is 198 in cumulative while NO is 314 also in cumulative.CONSIDERING THE 6 DISORDERs that was taken one after the other . it shows that the practitioners are all aware of the disorder but resulted into using suitable TMJ TREATMENT.

\subsection{Quality of the Protocol for Carrying out a Restoration}

The proportion of the practitioners who used clinical methods that consisted of an evaluation of the joint of the patient by asking them to clench their teeth until they achieved optimal comfort was $5.7 \%$. The vast majority $(94.3 \%)$ always used articulating paper to adjust the Maximal Intercuspal Occlusion (MOI). Most of the surgeons $(82.8 \%)$ noted that they carried out the polishing of amalgam restorations in a subsequent session. The precautions used to avoid TMJ disorders comprised taking into account the occlusal morphology at the time of shaping of the restorations for $32 \%$ of them and rigorous control of the occlusion after having undertaken the restoration for $55 \%$. The proportion of practitioners who systematically reevaluated the restoration in another session was $54 \%$.

\section{DISCUSSION}

The repartition according to the type of practice, allowed us to show that the two sectors of practice were represented nearly equally, that is to say, $49.5 \%$ of the practitioners were in the private sector and $50.5 \%$ in the public sector, with a sex ratio of 1.68. Nearly all took part in continued training $(89.7 \%)$. The sample was representative of all years of experience brackets and the most active categories were those that had more than 10 years of experience $(48 \%)$. Similar results have been reported by other studies. Indeed, Kaboré et al. in 2015 [10] and Fall et al. [11] in 2018, in Burkina Faso, also reported the same trends in terms of the public sector and continued post-university training. However, these authors had a high level (40\%) of young practitioners in their sample, that 
is to say, practitioners who had been in practice for less than 10 years. The work by Ndiaye et al. [12] in 2017 in Senegal and of Udoye et al. (2013) [13] in Nigeria also reported a predominance of males in the dental profession and a larger proportion in private practice.

The present study, although limited to the practitioners of the town of Abidjan, has allowed occlusion to be recognized as one of the foremost concerns of general practitioner dentists who perform restorative dentistry on a daily basis. Indeed, poorly suited restoration materials can impair occlusion and mandibular kinetics [14]. Conservative materials present great variability and they present different mechanical properties in terms of hardness [15], roughness [16] and elasticity modulus [17]. Additionally, some recently introduced conservative materials such as fiber reinforced composites [18] or $\mathrm{CAD} / \mathrm{CAM}$ restoratives [19] present different hardness and flexural properties if compared with conventional conservative materials, thus leading to different possibilities of correlation with TMJ. For this reason, the knowledge about this topic has to be constantly updated.

When dysfunction manifest, the clinical signs most often reported by the practitioners were joint pain (76\%) followed by cracking joint (64.4\%) and muscle pain (69.9\%). The etiological factors put forward were overhanging restorations for $49.4 \%$ of them. The objective of any occlusal restoration is to optimize masticatory function and to maintain dental health [20]. Occlusion is always involved to a certain degree in daily dental treatments [2]. By systematic screening, odontologists need to know how to recognize occlusion impairments, so as to at least avoid generating then by iatrogenic procedures [2]. Sudden occlusal changes can occur over the course of a restorative treatment with amalgam or composite resins that can lead to an overbite or an underbite [21]. When they are not tolerated, these changes in occlusion can lead to ineffective sensorimotor regulation $[22,23]$. Occlusal surfaces, due to their shape, constitute the working part of a tooth. Occlusal and root morphologies affect the functional ergonomics [2]. Each tooth has an essential functional and stabilizing role. The occlusal morphology of human teeth comprises convex shapes, elevations that are cusp-shaped or that have free edges. The cusp shape constitutes the ergonomic response to the physiological requirements. The morphology has a direction and needs to be respected, restored, or reconstructed [24, 25]. When the occlusal alignment is perturbed, so are the abilities of the manducatory apparatus, which is harmful to the various structures $[26,27,22]$. Such one-off occlusal anomalies (one or two teeth), having appeared or worsened recently, can be corrected by a straightforward equilibration of the first intention with the aim of immediate optimization of occlusal functions $[28,29]$. MAD can be clinically characterized by pain at the level of the TMJ and/or at the level of the masticatory muscles, as shown in this study. It can radiate to the eyes, the face, the shoulders, the neck, or the back. The patient may also state that they have headaches and otalgia [30]; which is also what practitioners have noted. Thus, while the symptoms of TMJ disorders can be unclear, they can be related to other pathologies [31 - 33]; whence the importance of a rigorous analysis that leads to a positive diagnosis. For the practitioners, the treatment of TMJ disorders amounted to selective grinding (70.1\%) and wearing an occlusal mouthguard (65.5\%) in advanced cases. Indeed, a mouthguard provides pain relief by muscle relaxation and by repositioning of the condyles $[34,28]$. This study has reported that the vast majority of the practitioners always used articulation paper $(94.3 \%)$ to evaluate the TMJ and $82.8 \%$ polished the amalgam restoration that they had carried out at a prior appointment. Physiologically, the TMJ constitutes a reference mandibular position whereby the relationship of the teeth is characterized by a maximum of interarcade contacts $[24,35]$. It should be noted that the term "intercuspation" comprises the notion of displacement; it hence signifies, not the position, but the movement of the mandible resulting in the maximal intercuspidal position [36, 37]. The role of occlusion is, therefore, not trivial, and its regulation abides with definite rules. This is why in practice its control and its regulation need to be carried out with great thoroughness $[38,39]$. When the skills of the practitioner are insufficient, the patient needs to be referred to a specialist, as indicated by more than half of the practitioners.

\section{CONCLUSION}

This study has shown that the general practitioners of the town of Abidjan have a good level of knowledge of the consequences of poorly carried out restorations? Such occlusion impairments typically produce improper muscle responses and lead to changes in pressure at the level of the temporomandibular joint. Hence, the need to follow the procedures for restoration so as not to generate them. Re-establishment of occlusal function, just like the sealing of coronal obturations, is indispensable for the longevity of restorations and thereby contributes to maintaining good-oro-dental health.

\section{ETHICS APPROVAL AND CONSENT TO PARTICIPATE}

Not applicable

\section{HUMAN AND ANIMAL RIGHTS}

No animals/humans were used for studies that are the basis of this research.

\section{CONSENT FOR PUBLICATION}

Not applicable.

\section{AVAILABILITY OF DATA AND MATERIALS:}

Not applicable.

FUNDING

None.

\section{CONFLICT OF INTEREST}

The authors declare no conflict of interest, financial or otherwise.

\section{ACKNOWLEDGEMENTS}

Declared none. 


\section{REFERENCES}

[1] Avoaka-Boni MC, Djolé XS, Gnagne-Koffi NDY, Koffi AFE, Koné Kane A, Mansilla EC. Place des restaurations coronaires foulées dans le traitement des dents délabrées: Enquête auprès des praticiens de la ville d'abidjan. Rev Col Odonto-Stomatol Afr Chir Maxillofac 2017; 24: 5-9.

[2] Orthlieb JD, Darmouni L, Pedinielli A, Jouvin Darmouni J. Fonctions occlusales: Aspects physiologiques de l'occlusion dentaire humaine. EMC - Odontologie 2013; 28-160-B: 1-10.

[3] Imfeld T, Krejci I, Lussi A, Lutz F, Mörmann WH. Médecine dentaire restauratrice: Lignes directrices relatives à la qualité. Swiss Dental J SSO 2015; 125: 1039-51.

[4] Schiffman E, Ohrbach R. Executive summary of the diagnostic criteria for temporomandibular disorders for clinical and research applications. J Am Dent Assoc 2016; 147(6): 438-45.

[http://dx.doi.org/10.1016/j.adaj.2016.01.007] [PMID: 26922248]

[5] Dym H, Israel H. Diagnosis and treatment of temporomandibular disorders. Dent Clin North Am 2012; 56(1): 149-161, ix. [http://dx.doi.org/10.1016/j.cden.2011.08.002] [PMID: 22117948]

[6] Manfredini D. Occlusal equilibration for the management of temporomandibular disorders. Oral Maxillofac Surg Clin North Am 2018; 30(3): 257-64.

[http://dx.doi.org/10.1016/j.coms.2018.04.002] [PMID: 29858130]

[7] Liu F, Steinkeler A. Epidemiology, diagnosis, and treatment of temporomandibular disorders. Dent Clin North Am 2013; 57(3): 465-79.

[http://dx.doi.org/10.1016/j.cden.2013.04.006] [PMID: 23809304]

[8] Manfredini D, Castroflorio T, Perinetti G, Guarda-Nardini L. Dental occlusion, body posture and temporomandibular disorders: Where we are now and where we are heading for. J Oral Rehabil 2012; 39(6): 463-71.

[http://dx.doi.org/10.1111/j.1365-2842.2012.02291.x] [PMID: 22435603]

[9] Orthlieb JD, Ré JP, Jeany M, Giraudeau A. Articulation temporomandibulaire, occlusion et bruxisme. Rev Stomatol Chir Maxillofac Chir Orale 2016; 117(4): 207-11 [PMID: 27523443]

[10] Kaboré WAD, Bane K, Fall M, Niang SO, Faye B. Problèmes terminologiques et facteurs étiologiques des lésions dentaires non carieuses. Enquête auprès de chirurgiens-dentistes burkinabè. Rev. Col. Odonto-Stomatol. Afr. Chir. Maxillo-fac 2015; 22: 5-10.

[11] Fall M, Ouédraogo Y, Millogo M, Diarra AA, Ouattara S, Konsem T. Prise en charge de l'édentement unitaire dans les cabinets dentaires de la ville de Ouagadougou. Rev Col Odonto-Stomatol Afr Chir Maxillofac 2018; 25: 46-51.

[12] Ndiaye ML, Lecor PA, Soumboundou S, Niang SO, Gueye PD, Touré B. Attitudes et connaissances des chirurgiens-dentistes sénégalais sur la radioprotection. Rev CAMES SANTE 2017; 5: 88-93.

[13] Udoye CI, Sede MA, Jafarzadeh H, Abbott PV. A survey of endodontic practices among dentists in Nigeria. J Contemp Dent Pract 2013; 14(2): 293-8.

[http://dx.doi.org/10.5005/jp-journals-10024-1316] [PMID: 23811662]

[14] Gnauck M, Magnusson T, Ekberg E. Knowledge and competence in temporomandibular disorders among Swedish general dental practitioners and dental hygienists. Acta Odontol Scand 2017; 75(6): 429-36.

[http://dx.doi.org/10.1080/00016357.2017.1331373] [PMID: 28554268]

[15] Khosravani MR. Mechanical behavior of restorative dental composites under various loading conditions. J Mech Behav Biomed Mater 2019; 93: 151-7.

[http://dx.doi.org/10.1016/j.jmbbm.2019.02.009] [PMID: 30798181]

[16] Poggio C, Dagna A, Chiesa M, Colombo M, Scribante A. Surface roughness of flowable resin composites eroded by acidic and alcoholic drinks. J Conserv Dent 2012; 15(2): 137-40.

[http://dx.doi.org/10.4103/0972-0707.94581] [PMID: 22557811]

[17] de Andrade GS, Tribst JP, Dal Piva AO, et al. A study on stress distribution to cement layer and root dentin for post and cores made of $\mathrm{CAD} / \mathrm{CAM}$ materials with different elasticity modulus in the absence of ferrule. J Clin Exp Dent 2019; 11(1): e1-8.

[http://dx.doi.org/10.4317/jced.55295] [PMID: 30697387]

[18] Scribante A, Vallittu PK, Özcan M. Fiber-Reinforced Composites for Dental Applications. BioMed Res Int 2018; 20184734986 [http://dx.doi.org/10.1155/2018/4734986] [PMID: 30515400]

[19] Ahlholm P, Lappalainen R, Lappalainen J, Tarvonen PL, Sipilä K. Challenges of the direct filling technique, adoption of cad/cam techniques, and attitudes toward $3 \mathrm{~d}$ printing for restorative treatments among finnish dentists. Int J Prosthodont 2019; 32(5): 402-10.

[http://dx.doi.org/10.11607/ijp.6343] [PMID: 31486810]

[20] Donovan TE, Marzola R, Murphy KR, et al. Annual review of selected scientific literature: A report of the committee on scientific investigation of the american academy of restorative dentistry. J Prosthet Dent 2018; 120(6): 816-78.

[http://dx.doi.org/10.1016/j.prosdent.2018.09.010] [PMID: 30545471]

[21] Mehta NR, Correa LP. Oral appliance therapy and temporomandibular disorders. Sleep Med Clin 2018; 13(4): 513-9.

[http://dx.doi.org/10.1016/j.jsmc.2018.08.001] [PMID: 30396445]

[22] Cortese S, Mondello A, Galarza R, Biondi A. Postural alterations as a risk factor for temporomandibular disorders. Acta Odontol Latinoam 2017; 30(2): 57-61.

[PMID: 29248939]

[23] Wieckiewicz M, Boening K, Wiland P, Shiau YY, Paradowska-Stolarz A. Reported concepts for the treatment modalities and pain management of temporomandibular disorders. J Headache Pain 2015; 16: 106-17.

[http://dx.doi.org/10.1186/s10194-015-0586-5] [PMID: 26644030]

[24] Türp JC, Schindler H. The dental occlusion as a suspected cause for TMDs: Epidemiological and etiological considerations. J Oral Rehabil 2012; 39(7): 502-12.

[http://dx.doi.org/10.1111/j.1365-2842.2012.02304.x] [PMID: 22486535]

[25] Fougeront N. Neurophysiologie de l'occlusion: Des sciences fondamentales à la pratique clinique. Actual Odontostomatol (Paris) 2018; 290: 1-13.

[http://dx.doi.org/10.1051/aos/2018043]

[26] Pontons-Melo JC, Pizzatto E, Furuse AY, Mondelli J. A conservative approach for restoring anterior guidance: A case report. J Esthet Restor Dent 2012; 24(3): 171-82.

[http://dx.doi.org/10.1111/j.1708-8240.2011.00483.x] [PMID: 22691078]

[27] Shah N, Melo L, Reid WD, Cioffi I. Masseter deoxygenation in adults at risk for temporomandibular disorders. J Dent Res 2019; 98(6): 666-72.

[http://dx.doi.org/10.1177/0022034519837249] [PMID: 30946624]

[28] Oltramari-Navarro PV, Yoshie MT, Silva RA, et al. Influence of the presence of temporomandibular disorders on postural balance in the elderly. CoDAS 2017; 29(2): e20160070-.

[http://dx.doi.org/10.1590/2317-1782/20172016070] 28198949]

[29] Clauzade M. L'occlusion dentaire. Rev d'Orthodontie Clin 2015; 12 : 2-16.

[http://dx.doi.org/10.1051/roc/20151202]

[30] Abduo J, Tennant M, McGeachie J. Lateral occlusion schemes in natural and minimally restored permanent dentition: A systematic review. J Oral Rehabil 2013; 40(10): 788-802

[http://dx.doi.org/10.1111/joor.12095] [PMID: 23981045]

[31] Stechman-Neto J, Porporatti AL, Porto de Toledo I, et al. Effect of temporomandibular disorder therapy on otologic signs and symptoms: A systematic review. J Oral Rehabil 2016; 43(6): 468-79. [http://dx.doi.org/10.1111/joor.12380] [PMID: 26749516]

[32] Bonnefoy C, Chikhani L, Dichamp J. Anatomie clinique de la douleur trigéminale: synthèse et applications en odonto-stomatologie. AOS 2017; 281: 1-10.

[33] Kharrat O, Zahar M, Aloulou I, et al. Rachialgies et dysfonction de l'appareil manducateur. Journal de Réadaptation Médicale: Pratique et Formation en Médecine Physique et de Réadaptation 2014; 34: 10-6.

[34] Buergers R, Kleinjung T, Behr M, Vielsmeier V. Is there a link between tinnitus and temporomandibular disorders? J Prosthet Dent 2014; $111(3): 222-7$

[http://dx.doi.org/10.1016/j.prosdent.2013.10.001] [PMID: 24286640]

[35] Oliveira SSI, Pannuti CM, Paranhos KS, et al. Effect of occlusal splint and therapeutic exercises on postural balance of patients with signs and symptoms of temporomandibular disorder. Clin Exp Dent Res 2019; 5(2): 109-15.

[http://dx.doi.org/10.1002/cre2.136] [PMID: 31049212]

[36] Butts R, Dunning J, Perreault T, Mettille J, Escaloni J. Pathoanatomical characteristics of temporomandibular dysfunction: Where do we stand? (Narrative review part 1). J Bodyw Mov Ther 2017; 21(3): 534-40.

[http://dx.doi.org/10.1016/j.jbmt.2017.05.017] [PMID: 28750961]

[37] Jiménez-Silva A, Tobar-Reyes J, Vivanco-Coke S, Pastén-Castro E, Palomino-Montenegro H. Centric relation-intercuspal position discrepancy and its relationship with temporomandibular disorders. A 
systematic review. Acta Odontol Scand 2017; 75(7): 463-74. [http://dx.doi.org/10.1080/00016357.2017.1340667] [PMID 28641068]

[38] De Rossi SS, Greenberg MS, Liu F, Steinkeler A. Temporomandibular disorders: evaluation and management. Med Clin North Am 2014;
98(6): 1353-84

[http://dx.doi.org/10.1016/j.mcna.2014.08.009] [PMID: 25443680]

[39] Racich MJ. Occlusion, temporomandibular disorders, and orofacial pain: An evidence-based overview and update with recommendations. J Prosthet Dent 2018; 120(5): 678-85.

[http://dx.doi.org/10.1016/j.prosdent.2018.01.033] [PMID: 29961622]

\section{2019 Avoaka-Boni et al.}

This is an open access article distributed under the terms of the Creative Commons Attribution 4.0 International Public License (CC-BY 4.0), a copy of which is available at: (https://creativecommons.org/licenses/by/4.0/legalcode). This license permits unrestricted use, distribution, and reproduction in any medium, provided the original author and source are credited. 